\title{
Integration effect of organic and inorganic nutrient sources on nutrient uptake of potato and soil properties in alluvial plains of Northern Bihar
}

\author{
MOHAN BABU YN*, DK DWIVEDI, DK ROY, SHANKAR JHA AND ANSHUMAN DWIVEDI
}

\begin{abstract}
A field experiment was conductedto study the response of potato (Solanum tuberosum L.) to integrated nutrient managementwith variety KufriAshoka. Treatments consisted of five levels of $\operatorname{RDF}(0,75,100,125,150 \%)$ and two sources of organic manures (farmyard manure @ $20.0 \mathrm{t} / \mathrm{ha}$ and spent mushroom substrate @ $4.0 \mathrm{t} / \mathrm{ha}$ ).The results revealed that there was a significant difference in various plant growth and yield parameters like growth, yield attributes and fresh yield of tubers, total nutrient uptake, the protein content of tuber and the fertility status of the post harvested soil. Application of $100 \%$ RDF coupled with FYM 20 t/ha or SMS 4 t/ha had performed well, found statistically at par to treatments, 125\% RDF and 150\% RDF integrated with FYM $20 \mathrm{t} /$ ha or SMS $4 \mathrm{t} /$ ha respectively.
\end{abstract}

KEYWORDS

Spent Mushroom Substrate (SMS), Nutrient Use Efficiency, Sustainable agriculture

\section{ARTICLE INFO}

\begin{tabular}{lll}
\hline Received on & $:$ & $15 / 11 / 2020$ \\
Accepted on & $:$ & $05 / 02 / 2021$ \\
Published online & $:$ & $19 / 03 / 2021$ \\
\hline
\end{tabular}

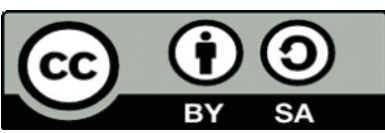

\section{INTRODUCTION}

$\mathrm{P}$ otato (Solanum tuberosum L.) a short duration, high nutrient responsive crop, is cultivated in 150 countries covering an area of 19.25 million hectares with a production of 376.83 million tonnes and productivity of 19.25 tonnes per hectare. It ranks fourth in the world and third in India concerning production. In 2050 potato demand in India is estimated to be 122 million tons, compared to 48.60 million tons, almost 2.5 times the current production. Potato is an economical food as it provides a source of low-cost energy to the human diet. The potato tubers are the rich source of starch, vitamin $\mathrm{C}$ and $\mathrm{B}$ and minerals. It contains $20.6 \%$ carbohydrates, $2.1 \%$ protein, $0.3 \%$ fat, $1.1 \%$ crude fiber and $0.9 \%$ ash (Khurana and Naik, 2003).At the present level of farm management practices, we can harvest only $42-45$ per cent of the achievable yield. Growth, yield and quality of potato depend on nutrient availability in soil, which is directly related to the judicious application of manures and fertilizers. Nitrogen, phosphorus and potassium are considered the most important macronutrient for the potato crop in Indian soil. Potato relatively demands a higher level of soil nutrients due to poorly developed and shallow root system in relation to yield (Perrenoud, 1993). Low recovery of applied nitrogen, fixation of phosphorus and deficiency of potassium limiting the potato growth and production. Balanced fertilization is a prerequisite for getting optimum yield potential of potato (Kushwah et al., 2005). Sustainable production of crops cannot be maintained by using chemical fertilizers alone because of deterioration in soil physical and biological environments (Kumar et al., 2008 Singh and Bhatt, 2013). Great opportunities exist to increase potato yield and quality by improving nutrient management. Integrated nutrient management (INM) involving a

Dr. Rajendra Prasad Central Agricultural University, Pusa, Samastipur, Bihar, India

*Corresponding author email : $\underline{\text { mohanbabu013@gmail.com }}$ combination of organic manure, fertilizersand management practices for balanced fertilization and sustainability of crop production on a long term basis (Singh et al., 2013; Hegde and Dwivedi, 1993). The basic objectives of integrated nutrient management (INM) are to reduce the inorganic fertilizer requirement, to restore organic matter in the soil, to enhance nutrient use efficiency and to maintain soil quality in terms of physical, chemical and biological properties. Keeping the above facts in view the present investigation was carried out tostudy the integration effect of organic \& inorganic sources of nutrients on nutrient uptake \& soil properties.

\section{MATERIALS AND METHODS}

A field experiment was conducted in the plot no. 13 during rabi season at Tirhut College of Agriculture Farm, Dholi (Muzaffarpur) which is located at an elevation of 52.18 meters above mean sea level and lies at $25^{\circ} .98^{\prime} \mathrm{N}$ latitude and $85^{\circ} .6^{\prime} \mathrm{E}$ longitude. The soil type of the experimental plot was calcareous alluvium in nature and slightly alkaline $(\mathrm{pH} 7.90$, electrical conductivity $0.24 \mathrm{dS} / \mathrm{m}$ ) in reaction, due to the deposition of sediments transported by the river Burhi Gandak through the ages. Observations on various growth and yield attributing characters were recorded by randomly selecting five competitive plants of each treatment in a replication, which were tagged properly. The growth and yield parameters of the crop during the experimental duration were recorded at regular intervals, in order to assess the probable relationship between growth attributes and the final yield. Five representative plants were not dehaulmed, as the data of vine yield and dry matter yield is essential at the time of harvest for the purpose of research studies. The fertility status of the experimental soil was categorized as low concerning organic carbon $(0.47 \%)$, available nitrogen $(244.60 \mathrm{~kg} / \mathrm{ha})$, potassium $(138.01 \mathrm{~kg} / \mathrm{ha})$ and medium for available phosphorous $(23.55$ $\mathrm{kg} / \mathrm{ha}$ ). The spent mushroom substrate was purchased from 
AICRP on Mushroom Research, RPCAU Pusa. FYM was procured from dairy unit Pusa. FYM and SMS were applied and mixed into the soil at 10 days before planting accordingly to the respective treatments scheduled.

Table 1 : Treatments details

\begin{tabular}{cl}
\hline Symbol & Description \\
\hline $\mathrm{T}_{1}$ & Control \\
$\mathrm{T}_{2}$ & $100 \% \mathrm{RDF}$ \\
$\mathrm{T}_{3}$ & $75 \% \mathrm{RDF}+20.0 \mathrm{t} / \mathrm{ha}$ Farm Yard Manure \\
$\mathrm{T}_{4}$ & $75 \% \mathrm{RDF}+4.0 \mathrm{t} / \mathrm{h}$ Spent Mushroom Substrate \\
$\mathrm{T}_{5}$ & $100 \% \mathrm{RDF}+20.0 \mathrm{t} / \mathrm{ha}$ Farm Yard Manure \\
$\mathrm{T}_{6}$ & $100 \% \mathrm{RDF}+4.0 \mathrm{t} / \mathrm{ha}$ Spent Mushroom Substrate \\
$\mathrm{T}_{7}$ & $125 \% \mathrm{RDF}+20.0 \mathrm{t} / \mathrm{ha}$ Farm Yard Manure \\
$\mathrm{T}_{8}$ & $125 \% \mathrm{RDF}+4.0 \mathrm{t} / \mathrm{ha}$ Spent Mushroom Substrate \\
$\mathrm{T}_{9}$ & $150 \% \mathrm{RDF}+20.0 \mathrm{t} / \mathrm{ha}$ Farm Yard Manure \\
$\mathrm{T}_{10}$ & $150 \% \mathrm{RDF}+4.0 \mathrm{t} / \mathrm{ha}$ Spent Mushroom Substrate \\
\hline
\end{tabular}

The nutrient management was accomplished as per formulated treatments in the experiment under study (Table 1). The fertilizer recommendation for the crop potato was 150:90:100 $\mathrm{kg} \mathrm{NPK} /$ ha. In treatment, $\mathrm{T}_{2}, 100 \%$ recommended dose of NPK was applied. A full dose of recommended $\mathrm{P}$ and $\mathrm{K}$ and half of the $\mathrm{N}$ was applied as a basal application. The leftover quantity of recommended $\mathrm{N}$ was applied at $45 \mathrm{DAP}$, respectively. Kufri Ashoka variety was selected for the experimental studies. Five representative plants were selected from each plot for recording observations of growth, yield and quality attributing characters of potato. Haulms were sliced from the bottom leaving the underground portion unaffected, 10 days before harvesting. For estimation of available nutrients in the soil, samples from the soil up to $30 \mathrm{~cm}$ depth from the surface was collected from each plot, shade dried, powdered and sieved through $2 \mathrm{~mm}$ mesh. After sieving the sample was stored in a glass bottle for chemical analysis of the soil. Harvested five representative plants from each plot are shade dried, then oven dried for 48 hours at $65^{\circ} \mathrm{C}$, powdered. The powdered samples were stored in a container for nutrient content analysis. The analysis was performed as per the standard methodology and procedure (Table 2). Based on the nutrient content in haulms and tuber at harvest of the crop, the uptake of NPK of potato was worked. The fresh yield of

Table 2 : Standard laboratory Methodology

\begin{tabular}{ll}
\hline Particulars & Methodology \\
\hline $\mathrm{pH}(1: 2.5)$ & Buckman pH meter (Jackson, 1967) \\
Electrical conductivity & Systronics electrical conductivity \\
(dS/m at $\left.25^{\circ} \mathrm{C}\right)$ & meter (Richards, 1954) \\
Organic carbon (\%) & Walkley and Black method \\
& (Walkley and Black, 1934) \\
Available Nitrogen (kg & Alkaline permanganate method \\
$\mathrm{N} / \mathrm{ha})$ & (Subbiah and Asija, 1956) \\
Available Phosphorus & Olsen's method (0.5 N NaHCO3 \\
(kg/ha) & extractable) (Olsen et al.,1954) \\
AvailablePotassium (kg /ha) & Flame photometric method \\
& (Jackson, 1967) \\
\hline
\end{tabular}

tubers and vine in $\mathrm{kg}$ was multiplied with a value of 0.155 to get a dry yield of tubers and vines. The protein content of tuber was calculated by multiply the per cent nitrogen in tuber with a constant factor of 6.25 .

Data concerning multiple parameters were subjected to statistical study with the method of analysis of variance. The significance of the treatment impact was examined by the $\mathrm{F}$ test with critical differences value at a $5 \%$ level of significance were computed.

\section{RESULTS AND DISCUSSION}

Effect of of organic and inorganic nutrient sources on growth and yield attributes of potato

The data presented in Table 2 indicate that potato crop raised under various treatments had a significant response on growth and yield attributes. Among different treatments, treatmentplot receiving $150 \%$ RDF+ 20 t/ha FYM, registered higher plant height $(48.80 \mathrm{~cm})$, number of shoots (5.87/plant) and dry matter production (70.16 g/plant),fresh yield of tuber per plant,( $359.63 \mathrm{~g} /$ plant), total tuber yield (265.29 q/ha), and biomass yield(379.11 q/ha), was found statistically at par with with treatments $100 \%, 125 \%$ and $150 \%$ RDF integrated with FYM 20 t/ha and SMS 4 t/ha respectively and significantly superior over rest of the treatments. The increment in plant height, number of shoots and leaves per plant with an increase in fertilizers dosage coupled with organic manures could clearly indicate that application of organic manures to the soil in concurrence with mineral fertilizers, which could have significantly enhanced the nutrient availability, leading to beneficial impact on growth parameters as indicated by (Youtrchi et al., 2013). The higher yield achieved by applying a higher fertilizer dose (NPK) may be due to the positive reaction of potato crop to nutrients such as nitrogen, phosphorus and potash. In general N, P and $\mathrm{K}$ had a profound effect on the size of tuber. $\mathrm{N}$ and $\mathrm{P}$ influenced tuber formation in potato by influencing the activity and phytohormone balance of the plant especially, on gibberellin, abscisic acid and cytokin in levels. Potassium application promotes the activation of a number of enzymes involved in photosynthesis, carbohydrate, protein metabolism and helps to translocation carbohydrates from leaves to tubers. Organic manure in the soil improves nitrogen mineralization, plant absorption of phosphorus, by promoting carbonic acid production the acid that increases the solubility of phosphate compounds. Organic manures also supply micro nutrients and enhance the soil physico-chemical characteristics resulting in enhanced nutrient uptake that would have increased the yield of large sized tubers. The FYM has been found to be superior than SMS because it is bulky in nature and provides more quantities of available macro and micro nutrients. The FYM nutrient release was faster than SMS since the rate of mineralization of SMS was slow. These experimental results are in close agreement with the findings of Alam et al. (2007), Sarkar et al. (2011), Baishya et al. (2013), Sharma and Kumar (2014) and Kumar et al. (2017). 
Table 3: Effect of organic and inorganic nutrient sources on growth and yield attributes of potato

\begin{tabular}{|c|c|c|c|c|c|c|}
\hline Treatments & Plant height & $\begin{array}{c}\text { Number of } \\
\text { shoots per } \\
\text { plant }\end{array}$ & $\begin{array}{c}\text { Dry matter } \\
\text { accumulation } \\
\text { (g/plant) }\end{array}$ & $\begin{array}{c}\text { Tuber } \\
\text { yield } \\
\text { (g/plant) }\end{array}$ & $\begin{array}{l}\text { Fresh Yield of } \\
\text { Tubers (q/ha) }\end{array}$ & $\begin{array}{c}\text { Biomass } \\
\text { Yield } \\
\text { (q/ha) }\end{array}$ \\
\hline $\mathrm{T}_{1}-$ Control & 31.48 & 3.33 & 41.20 & 151.34 & 110.48 & 182.89 \\
\hline $\mathrm{T}_{2}-100 \% \mathrm{RDF}$ & 39.57 & 4.87 & 57.50 & 279.19 & 225.95 & 329.34 \\
\hline $\mathrm{T}_{3}-75 \%$ RDF + 20.0 t/ha FYM & 38.83 & 4.80 & 56.12 & 276.27 & 229.56 & 332.31 \\
\hline $\mathrm{T}_{4}-75 \% \mathrm{RDF}+4.0 \mathrm{t} / \mathrm{ha} \mathrm{SMS}$ & 38.52 & 4.67 & 54.81 & 265.43 & 228.21 & 330.48 \\
\hline $\mathrm{T}_{5}-100 \% \mathrm{RDF}+20.0$ t/ha FYM & 44.26 & 5.33 & 65.45 & 340.92 & 252.11 & 361.01 \\
\hline $\mathrm{T}_{6}-100 \% \mathrm{RDF}+4.0 \mathrm{t} / \mathrm{ha}$ SMS & 44.49 & 5.30 & 64.80 & 336.35 & 248.15 & 356.78 \\
\hline $\mathrm{T}_{7}-125 \% \mathrm{RDF}+20.0$ t/ha FYM & 47.59 & 5.73 & 68.24 & 350.88 & 260.29 & 372.32 \\
\hline $\mathrm{T}_{8}-125 \% \mathrm{RDF}+4.0 \mathrm{t} / \mathrm{ha} \mathrm{SMS}$ & 46.37 & 5.67 & 67.35 & 345.43 & 258.11 & 369.90 \\
\hline $\mathrm{T}_{9}-150 \% \mathrm{RDF}+20.0 \mathrm{t} / \mathrm{ha} \mathrm{FYM}$ & 48.80 & 5.87 & 70.16 & 359.63 & 265.29 & 379.11 \\
\hline $\mathrm{T}_{10}-150 \% \mathrm{RDF}+4.0 \mathrm{t} / \mathrm{ha} \mathrm{SMS}$ & 47.75 & 5.80 & 69.73 & 351.96 & 261.72 & 374.52 \\
\hline $\operatorname{SEm}( \pm)$ & 2.01 & 0.18 & 1.76 & 7.41 & 5.54 & 10.12 \\
\hline $\mathrm{CD}(p=0.05)$ & 6.44 & 0.58 & 5.63 & 23.70 & 17.72 & 32.38 \\
\hline
\end{tabular}

Effect of of organic and inorganic nutrient sources on nutrient content, uptake by potato

A close scrutiny of mean data concerning nutrient content, uptake by potato tubers, vine and protein content in tuber revealed that graded level of NPK with integration of organic manures (FYM and SMS) exerted significant difference. The data represented in Table 4 regarding nitrogen content, uptake by potato tubers, vinesand protein content in tuber was increased significantly in response to increasing the rate of fertilizer level along with organic manure (FYM and SMS) from null up to the highest rate of the recommended fertilizer. The per cent nitrogen content, and nitrogen uptake by tubers $(2.08 \%, 81.54 \mathrm{~kg} / \mathrm{ha})$, vines $(1.46 \%, 25.06 \mathrm{~kg} / \mathrm{ha})$, protein content $(13.00 \%)$ and total $\mathrm{N}$-uptake $(106.60 \mathrm{~kg} / \mathrm{ha})$ was found maximum in the plot receiving $150 \%$ RDF+ 20 t/ha FYM, which was found statistically at par with treatments $100 \%, 125 \%$ and $150 \%$ RDF integrated with FYM 20 t/ha and SMS 4 t/ha respectively and significantly superior over rest of the treatments.

Table 4 : Effect of different treatments on $\mathrm{N}$ - content, protein content and uptake in potato

\begin{tabular}{|c|c|c|c|c|c|c|}
\hline Treatment & $\begin{array}{c}\mathrm{N} \text {-content in } \\
\text { tuber }(\%)\end{array}$ & $\begin{array}{l}\text { N-content in } \\
\text { vine }(\%)\end{array}$ & $\begin{array}{c}\text { Protein content } \\
(\%)\end{array}$ & $\begin{array}{l}\text { N-uptake by } \\
\text { tuber (kg/ha) }\end{array}$ & $\begin{array}{l}\text { N-uptake by } \\
\text { vine }(\mathrm{kg} / \mathrm{ha})\end{array}$ & $\begin{array}{c}\text { Total uptake } \\
(\mathrm{kg} / \mathrm{ha})\end{array}$ \\
\hline $\mathrm{T}_{1}-$ Control & 1.66 & 1.04 & 10.38 & 28.46 & 11.68 & 40.14 \\
\hline $\mathrm{T}_{2}-100 \% \mathrm{RDF}$ & 1.88 & 1.29 & 11.75 & 65.81 & 20.66 & 86.46 \\
\hline $\mathrm{T}_{3}-75 \%$ RDF + $20.0 \mathrm{t} / \mathrm{ha} \mathrm{FYM}$ & 1.83 & 1.24 & 11.44 & 65.14 & 19.78 & 84.92 \\
\hline $\mathrm{T}_{4}-75 \% \mathrm{RDF}+4.0 \mathrm{t} / \mathrm{ha} \mathrm{SMS}$ & 1.80 & 1.21 & 11.25 & 63.60 & 19.17 & 82.76 \\
\hline $\mathrm{T}_{5}-100 \% \mathrm{RDF}+20.0 \mathrm{t} / \mathrm{ha} \mathrm{FYM}$ & 1.97 & 1.38 & 12.31 & 76.46 & 23.33 & 99.78 \\
\hline $\mathrm{T}_{6}-100 \% \mathrm{RDF}+4.0 \mathrm{t} / \mathrm{ha} \mathrm{SMS}$ & 1.94 & 1.35 & 12.13 & 75.37 & 22.72 & 98.10 \\
\hline $\mathrm{T}_{7}-125 \% \mathrm{RDF}+20.0 \mathrm{t} / \mathrm{ha} \mathrm{FYM}$ & 2.04 & 1.43 & 12.75 & 79.50 & 24.46 & 103.96 \\
\hline $\mathrm{T}_{8}-125 \% \mathrm{RDF}+4.0 \mathrm{t} / \mathrm{ha} \mathrm{SMS}$ & 1.99 & 1.39 & 12.44 & 77.58 & 23.77 & 101.34 \\
\hline $\mathrm{T}_{9}-150 \% \mathrm{RDF}+20.0 \mathrm{t} / \mathrm{ha} \mathrm{FYM}$ & 2.08 & 1.46 & 13.00 & 81.54 & 25.06 & 106.60 \\
\hline $\mathrm{T}_{10}-150 \% \mathrm{RDF}+4.0 \mathrm{t} / \mathrm{ha} \mathrm{SMS}$ & 2.05 & 1.44 & 12.81 & 80.17 & 24.99 & 105.16 \\
\hline $\operatorname{SEm}( \pm)$ & 0.06 & 0.04 & 0.35 & 2.02 & 0.83 & 2.69 \\
\hline $\mathrm{CD}(p=0.05)$ & 0.18 & 0.12 & 1.12 & 6.47 & 2.65 & 8.59 \\
\hline
\end{tabular}

Citation of the average data concerning on phosphorus and potassium content in tuber, vines, uptake by tuber, vine at harvest stage on dry weight basis as influenced through graded levels of NPK integrated with organic manures (FYM and SMS) are explained and presented in Table 5 and 6. Application of $150 \% \mathrm{RDF}+20.0 \mathrm{t} / \mathrm{ha}$ FYM registered the maximum content and uptakes of phosphorousin tubers $(0.60$ $\% 24.01 \mathrm{~kg} / \mathrm{ha})$, vines $(0.58 \%, .97 \mathrm{~kg} / \mathrm{ha})$, and potassium in tubers $(2.56 \%, 100.97 \mathrm{~kg} / \mathrm{ha})$ in vines $(1.38 \%, 24.02 \mathrm{~kg} / \mathrm{ha})$, total P -uptake (33.98 kg/ha) and K-uptake (124.99 $\mathrm{kg} / \mathrm{ha}$ )which was found statistically at par with treatments $100 \%, 125 \%$ and $150 \%$ RDF integrated with FYM 20 t/ha and SMS $4 \mathrm{t} /$ ha respectively and significantly superior over rest of the treatments.
The increase in nutrient content and uptake in potato tuber and vines was due to increased nutrient supply by inorganic and organic sources primarily $\mathrm{N}, \mathrm{P}$ and $\mathrm{K}$, organic manures supply plant nutrients throughout the growing period because of their slow mineralization rate. Addition of organic manures improve soil physical properties promoting better root growth and absorption of nutrients from the soil and also enhances the activity of beneficial microorganisms in the rhizosphere of the plant. However, further increases in nutrients dosage, total nutrient content and uptake in plants obey the law of diminishing returns. The protein level in the tuber was directly related to the amount of nitrogen content in the tuber, as nitrogen is an essential component for amino acid synthesis, which is necessary for the synthesis of proteins. 
Table 5: Effect of different treatments on P-content and uptake in potato

\begin{tabular}{|c|c|c|c|c|c|}
\hline Treatment & $\begin{array}{l}\text { P-content } \\
\text { in tuber }(\%)\end{array}$ & $\begin{array}{c}P \text {-content in } \\
\text { vine }(\%)\end{array}$ & $\begin{array}{l}\text { P-uptake by } \\
\text { tuber (kg/ha) }\end{array}$ & $\begin{array}{c}\text { P-uptake } \\
\text { by vine (kg/ha) }\end{array}$ & $\begin{array}{c}\text { Total uptake } \\
\text { (kg/ha) }\end{array}$ \\
\hline $\mathrm{T}_{1}-$ Control & 0.38 & 0.33 & 6.48 & 3.74 & 10.22 \\
\hline $\mathrm{T}_{2}-100 \% \mathrm{RDF}$ & 0.54 & 0.52 & 18.98 & 8.33 & 27.31 \\
\hline $\mathrm{T}_{3}-75 \% \mathrm{RDF}+20.0 \quad \mathrm{t} / \mathrm{ha} \mathrm{FYM}$ & 0.52 & 0.50 & 18.58 & 7.92 & 26.51 \\
\hline $\mathrm{T}_{4}-75 \% \mathrm{RDF}+4.0 \mathrm{t} / \mathrm{ha} \mathrm{SMS}$ & 0.51 & 0.49 & 18.18 & 7.69 & 25.87 \\
\hline $\mathrm{T}_{5}-100 \% \mathrm{RDF}+20.0 \mathrm{t} / \mathrm{ha} \quad \mathrm{FYM}$ & 0.57 & 0.56 & 22.12 & 9.39 & 31.51 \\
\hline $\mathrm{T}_{6}-100 \% \mathrm{RDF}+4.0 \mathrm{t} / \mathrm{ha} \mathrm{SMS}$ & 0.56 & 0.55 & 21.90 & 9.32 & 31.22 \\
\hline T7-125 \% RDF + 20.0 t/ha FYM & 0.59 & 0.57 & 23.56 & 9.86 & 33.43 \\
\hline $\mathrm{T}_{8}-125 \% \quad \mathrm{RDF}+4.0 \mathrm{t} / \mathrm{ha} \quad \mathrm{SMS}$ & 0.58 & 0.56 & 23.38 & 9.79 & 33.16 \\
\hline $\mathrm{T}_{9}-150 \% \mathrm{RDF}+20.0 \mathrm{t} /$ ha FYM & 0.60 & 0.58 & 24.01 & 9.97 & 33.98 \\
\hline $\mathrm{T}_{10}-150 \% \mathrm{RDF}+4.0 \mathrm{t} / \mathrm{ha} \quad \mathrm{SMS}$ & 0.59 & 0.56 & 23.89 & 9.90 & 33.79 \\
\hline $\operatorname{SEm}( \pm)$ & 0.02 & 0.01 & 0.67 & 0.29 & 0.88 \\
\hline $\mathrm{CD}(p=0.05)$ & 0.05 & 0.04 & 2.13 & 0.93 & 2.83 \\
\hline
\end{tabular}

Table : Effect of different treatments on $\mathrm{K}$ - content and uptake in potato

\begin{tabular}{|c|c|c|c|c|c|}
\hline Treatment & $\begin{array}{c}\text { K-content in } \\
\text { tuber }(\%)\end{array}$ & $\begin{array}{c}\text { K-content in } \\
\text { vine }(\%)\end{array}$ & $\begin{array}{l}\text { K-uptake by } \\
\text { tuber (kg/ha) }\end{array}$ & $\begin{array}{l}\text { K-uptake by } \\
\text { vine (kg/ha) }\end{array}$ & $\begin{array}{c}\text { Total uptake } \\
\text { (kg/ha) }\end{array}$ \\
\hline $\mathrm{T}_{1}-$ Control & 2.00 & 0.94 & 34.23 & 10.60 & 44.83 \\
\hline $\mathrm{T}_{2}-100 \% \mathrm{RDF}$ & 2.13 & 1.18 & 82.07 & 19.24 & 101.30 \\
\hline $\mathrm{T}_{3}-75 \%$ RDF + $20.0 \quad \mathrm{t} / \mathrm{ha} \mathrm{FYM}$ & 2.17 & 1.19 & 80.63 & 19.05 & 99.69 \\
\hline $\mathrm{T}_{4}-75 \% \mathrm{RDF}+4.0 \mathrm{t} / \mathrm{ha} \mathrm{SMS}$ & 2.12 & 1.17 & 79.71 & 18.56 & 98.28 \\
\hline$T_{5}-100 \%$ RDF $+20.0 \mathrm{t} / \mathrm{ha} \quad \mathrm{FYM}$ & 2.39 & 1.30 & 94.07 & 21.96 & 116.03 \\
\hline $\mathrm{T}_{6}-100 \% \mathrm{RDF}+4.0 \mathrm{t} / \mathrm{ha}$ SMS & 2.40 & 1.28 & 93.79 & 21.59 & 115.39 \\
\hline $\mathrm{T}_{7}-125 \% \mathrm{RDF}+20.0 \mathrm{t} / \mathrm{ha} \mathrm{FYM}$ & 2.51 & 1.35 & 98.73 & 23.14 & 121.86 \\
\hline $\mathrm{T}_{8}-125 \% \mathrm{RDF}+4.0 \mathrm{t} / \mathrm{ha} \mathrm{SMS}$ & 2.46 & 1.31 & 97.94 & 22.89 & 120.83 \\
\hline $\mathrm{T}_{9}-150 \% \mathrm{RDF}+20.0 \mathrm{t} / \mathrm{ha} \mathrm{FYM}$ & 2.56 & 1.38 & 100.97 & 24.02 & 124.99 \\
\hline $\mathrm{T}_{10}-150 \% \mathrm{RDF}+4.0 \mathrm{t} / \mathrm{ha} \mathrm{SMS}$ & 2.52 & 1.36 & 99.61 & 23.90 & 123.51 \\
\hline $\operatorname{SEm}( \pm)$ & 0.07 & 0.04 & 2.68 & 0.77 & 3.11 \\
\hline $\mathrm{CD}(p=0.05)$ & 0.22 & 0.12 & 8.58 & 2.46 & 9.95 \\
\hline
\end{tabular}

Similar results are also observed in Kumar et al.(2011), Lakshmi et al. (2012), Islam et al. (2013).

Effect of organic and inorganic nutrient sources on $\mathrm{pH}$, electrical conductivity, organic matter, available $\mathrm{N}, \mathrm{P}_{2} \mathrm{O}_{5}$ and $\mathrm{K}_{2} \mathrm{O}$ of post-harvest soil

Post harvest analysis of soil $\mathrm{pH}$ and electrical conductivity $(\mathrm{dS} / \mathrm{m})$ revealed that there were no significant differences in $\mathrm{pH}$ and electrical conductivity among all the treatments in the field experimentation. However the maximum $\mathrm{pH}$ (8.26) and electrical conductivity $(0.25 \mathrm{dS} / \mathrm{m})$ was observed in the treatment $75 \% \mathrm{RDF}+4.0 \mathrm{t} / \mathrm{ha}$ SMS. The $\mathrm{pH}$ and electrical conductivity were found minimum in the treatment $150 \%$ $\mathrm{RDF}+20.0 \mathrm{t} / \mathrm{ha}$ FYM $(7.78,0.22 \mathrm{dS} / \mathrm{m})$ respectively. The release of organic acids like humic and carbonic acids during the mineralization of organic manures enhances the $\mathrm{H}^{+}$ion activity results in a slight decrease in $\mathrm{pH}$ was observed.. Similar findings also reported by Kumar et al. (2017). Integration of organic and inorganic sources of nutrients exerted a significant effect on organic carbon, organic matter content and available N, P, and $\mathrm{K}$ in post-harvest soil. The mean data presented in Table 7 revealed that maximum content of organic matter $(0.90 \%)$ was observed in the treatments $125 \%$ RDF + 20.0 t/ha FYM $150 \%$ RDF + 20.0 t/ha FYMand $150 \%$ RDF + 4.0 t/ha SMS, were found significantly superior over control $(0.67 \%)$ and 100 per cent recommended dose of fertilizer $(0.76 \%)$ and remained statistically at par with other treatments. In this study increase in nutrient dosage, a slight increase in the percentage of organic matter was observed due to the external application of organic manures like FYM and SMS which enhanced the soil organic matter. Similarly, the availability of nitrogen, phosphorous and potassium was found maximum in the treatment $150 \% \mathrm{RDF}+$ 20.0 t/ha FYM (272.88, 32.06 and 157.81 NPK kg/ha) which was found statistically at par with treatments $100 \%, 125 \%$ and 150\% RDF integrated with FYM 20 t/ha and SMS 4 t/ha and significantly superior over rest of the treatments.

Applying organic manures along with increased levels of fertilizers to the soil will enhance the labile pool concentration of major nutrients and organic carbon content. Organic matter in the soil triggers the microbial activity and releases nitrogen through mineralization of applied organic matter. Phosphorus fertilizers and manure in the soil increase the available P status of soil which might be attributed to the build-up of available P owing to the production of carbonic acid, the acid that increases the solubility of phosphate 
Table 7: Effect of different treatments on $\mathrm{pH}$, electrical conductivity, organic matter, available $\mathrm{N}, \mathrm{P}_{2} \mathrm{O}_{5}$ and $\mathrm{K}_{2} \mathrm{O}$ of post-harvest soil

\begin{tabular}{|c|c|c|c|c|c|c|}
\hline Treatment & $\mathrm{pH}$ & $\begin{array}{c}E C \\
(\mathrm{dS} / \mathrm{m})\end{array}$ & $\begin{array}{c}\text { Organic } \\
\text { matter (\%) }\end{array}$ & $\begin{array}{c}\text { Nitrogen } \\
\text { (kg/ha) }\end{array}$ & $\begin{array}{c}\text { Phosphorous } \\
\text { (kg/ha) }\end{array}$ & $\begin{array}{c}\text { Potassium } \\
\text { (kg/ha) }\end{array}$ \\
\hline $\mathrm{T}_{1}-$ Control & 7.97 & 0.24 & 0.67 & 166.52 & 21.36 & 98.86 \\
\hline $\mathrm{T}_{2}-100 \% \mathrm{RDF}$ & 7.97 & 0.23 & 0.76 & 202.06 & 25.19 & 138.21 \\
\hline $\mathrm{T}_{3}-75 \% \mathrm{RDF}+20.0 \mathrm{t} / \mathrm{ha} \mathrm{FYM}$ & 8.10 & 0.24 & 0.84 & 233.42 & 27.38 & 139.31 \\
\hline $\mathrm{T}_{4}-75 \%$ RDF + $4.0 \mathrm{t} / \mathrm{ha} \mathrm{SMS}$ & 8.26 & 0.25 & 0.83 & 227.88 & 26.84 & 137.02 \\
\hline $\mathrm{T}_{5}-100 \% \mathrm{RDF}+20.0 \mathrm{t} / \mathrm{ha} \mathrm{FYM}$ & 7.83 & 0.23 & 0.86 & 256.60 & 30.57 & 148.34 \\
\hline $\mathrm{T}_{6}-100 \% \mathrm{RDF}+4.0 \mathrm{t} / \mathrm{ha} \mathrm{SMS}$ & 8.05 & 0.24 & 0.86 & 248.56 & 29.48 & 147.39 \\
\hline $\mathrm{T}_{7}-125 \% \mathrm{RDF}+20.0 \mathrm{t} / \mathrm{ha} \mathrm{FYM}$ & 8.08 & 0.24 & 0.90 & 265.78 & 31.22 & 155.34 \\
\hline $\mathrm{T}_{8}-125 \% \mathrm{RDF}+4.0 \mathrm{t} / \mathrm{ha} \mathrm{SMS}$ & 7.85 & 0.22 & 0.88 & 259.05 & 30.82 & 153.91 \\
\hline $\mathrm{T}_{9}-150 \% \mathrm{RDF}+20.0 \mathrm{t} / \mathrm{ha} \mathrm{FYM}$ & 7.78 & 0.22 & 0.90 & 272.88 & 32.06 & 157.81 \\
\hline $\mathrm{T}_{10}-150 \% \mathrm{RDF}+4.0 \mathrm{t} / \mathrm{ha} \mathrm{SMS}$ & 7.87 & 0.23 & 0.90 & 266.60 & 31.77 & 156.69 \\
\hline $\operatorname{SEm}( \pm)$ & 0.23 & 0.01 & 0.03 & 8.00 & 0.85 & 4.23 \\
\hline $\mathrm{CD}(p=0.05)$ & NS & NS & 0.09 & 25.59 & 2.71 & 13.53 \\
\hline
\end{tabular}

compounds and other chelating agents which form soluble complexes with native $\mathrm{P}$ in soils. The increase in available $\mathrm{K}$ may be due to the higher application of $\mathrm{K}$ along with organic manures which was advantageous as they improve soil physical and chemical properties. Organic manures also supply micronutrients, maintain healthy positive nutrient balance due to an increase in soil cation exchange capacity, water holding capacity and finally soil fertility levels by improving the activity of beneficial soil microbial population which helps in mineralization and mobilization of nutrients. The experimental results observed in the present research work on nutrient status were supported by the findings of Patel (2013) and Kumar et al.(2017)in potato.

\section{CONCLUSION}

Based on results obtained in the present investigation,the highest tuber yield was observed in 150\% RDF + 20.0 t/ha FYM

\section{REFERENCES}

Alam, MN, Jahan, MS, Ali, M.K., Ashraf, MA and Islam, MK 2007. Effect of vermicompost and chemical fertilizers on growth, yield and yield components of potato in barind soils of Bangladesh. Journal of Applied Sciences Research, 3(12): 1879-1888.

Baishya, LK, Gupta, VK, Lal, SS, Das, BK and Kumar, M 2013. Effect of biofertilizers on growth and yield of potato in north eastern hills of India. Potato Journal, 32: 3-4.

Hegde DM and Dwivedi BS. 1993.Integrated nutrient management for dryland agriculture. Fertilizer News 39:19-26.

Islam MM, Akhter S, Majid NM, Jannatul Ferdous JF and Alam MS. 2013. Integrated nutrient management for potato (Solanum tuberosum) in grey terrace soil (Aric Albaquipt). Australian Journal of Crop Science 7(9): 1235-1241.

Jackson ML 1967. Soil Chemical Analysis. Prentice-Hall of India, Pvt. Ltd. New Delhi. pp. 42-48.

Khurana SMP and Naik PS. 2003. The Potato Production and Utilization in Sub-tropics. The Potato. Mehta Publication. New Delhi, India. pp 1-14.

Kumar M, Baishya LK, Ghosh DC and Gupta VK. 2011. Yield and quality of potato (Solanum tuberosum) tubers as influenced by nutrient sources under rainfed condition of Meghalaya. Indian Journal of Agronomy 56 (3):260-266. treatment, it was found statistically at par with treatments $\mathrm{T}_{5}$ $100 \% \mathrm{RDF}+20.0 \mathrm{t} / \mathrm{ha} \mathrm{FYM}$ and $\mathrm{T}_{6}-100 \% \mathrm{RDF}+4.0 \mathrm{t} / \mathrm{ha}$ SMS.The total $\mathrm{N}, \mathrm{P}$ and $\mathrm{K}$ content and uptake by potato was significantly influenced by various treatments. The total N, P and $\mathrm{K}$ uptake by the potato crop was found maximum in treatment $150 \%$ RDF+20.0 t/ha FYM. The minimum uptake of nutrient by potato crop was observed in Control treatment. Addition of $150 \%$ RDF coupled with 20 t/ha FYM to the soil registered higher, per cent organic carbon, available $\mathrm{N}, \mathrm{P}_{2} \mathrm{O}_{5}$ and $\mathrm{K}_{2} \mathrm{O}$ content of the soil, was being statistically at par with treatments $125 \%$ RDF + 20.0 t/ha FYM' $150 \%$ RDF + 20.0 t/ha FYM and $150 \%$ RDF +4.0 t/ha SMS, For sustainable potato crop production as well as enhancing the soil nutrient status, application of $100 \% \mathrm{RDF}+20 \mathrm{t} /$ ha farm yard manure or $100 \%$ $\mathrm{RDF}+4.0 \mathrm{t} / \mathrm{ha}$ spent mushroom substrate are recommended under calcareous soil of northern Bihar.

Kumar P, Kumar A, Kumar N, Ahamad A and Verma MK. 2017. Effect of integrated nutrient management on productivity and nutrients availability of potato. International Journal of Current Microbiology and Applied Sciences 6(3): 1429-1436

Kumar P, Trehan SP, Singh BP, Rawal S and Khan MA. 2008. Precising nitrogen requirement of table potato (Solanum tuberosum L.) cultivars for different growth periods. Indian of Potato Association 28(1): 60-61

Kushwah VS, Singh SP and Lal SS.2005. Effect of manures and fertilizers on potato (Solanum tuberosum) production. Potato Journal 32(3-4): 157-158.

Lakshmi DV, Padmaja G and Rao PC. 2012. Effect of levels of nitrogen and potassium on soil available nutrient status and yield of potato (Solanum tuberosum L.). Indian Journal of Agricultural Research 46(1): 36-41

Olsen SR. 1954. Estimation of available phosphorus in soil by extraction with sodium bicarbonate. USDA Circular 939: 1-19.

Patel B. 2013. Effect of different levels of N, P and K on growth, development and yield of potato cv.Kufri Ashoka under Chhattisgarh plain condition. M. Sc. (Ag) Thesis IGKV, Raipur. pp. 70-71.

Perrenoud S. 1993. Fertilizing for high yield potato. IPI Bulletin 8. $2^{\text {nd }}$ Edition. International Potash Institute, Basel, Switzerland.

Richards LA.1954. Diagnosis and improvement of saline and alkali 
soils. Agricultural handbook 60. U.S. Dept. of Agriculture, Washington D.C., pp 160.

Sarkar, A., Sarkar, S. and Zaman, A. 2011. Growth and yield of potato as influenced by combination of organic manures and inorganic fertilizers. Potato Journal, 38(1): 78-80.

Sharma, K. A. and Kumar, V. 2014. Effect of varying levels of nitrogen and plant density on the production behavior of undersize seed tubers of potato (Solanumtuberosum L.) in northwestern hills of India. Indian Journal of Agricultural Sciences, 84(3): 407-410.

Singh AK and Bhatt BP. 2013. Effects of foliar application of zinc on growth and seed yield of late-sown lentil. Indian J. Agril. Sci. 83 (6): 622-626.
Singh AK, Singh KA, Bharati RC and Chadra N.2013.Response of intercrops and nutrient management on the performance of tobacco based intercropping system and assessment of system sustainability. Bangladesh J. Bot.42(2):343-348.

Subbiah BV and Asija GL.1956. A rapid method for the estimation of nitrogen in soil. Current Science 26: 259-260.

Walkley AJ and Black IA. 1934. Estimation of soil organic carbon by the chromic acid titration

Youtrchi, M.S., Hadi, M.H.S. and Darzi, M.T. 2013. Effect of nitrogen fertilizer and vermicompost on vegetative growth, yield and NPK uptake by tuber of potato. International Journal of Agriculture and Crop Sciences, 5(18): 2033-2040.method. Soil Science37: 29-38. 